Eur. J. Clin. Chem. Clin. Biochem.

Vol. 30, 1992, pp. $861-866$

(C) 1992 Walter de Gruyter \& Co. Berlin $\cdot$ New York

\title{
Validation of the Ultrafiltration Technique for Creatinine Analysis by HPLC: A Comparison with Direct Serum Injection
}

\author{
By L. Zwang and B. G. Blijenberg \\ Department of Clinical Chemistry, Academic Hospital Rotterdam-Dijkzigt, The Netherlands
}

(Received March 30/August 3, 1992)

\begin{abstract}
Summary: The determination of creatinine by HPLC was performed by direct injection of serum onto the column, and after ultrafiltration of the sample, and the results were compared. A modified weak cation exchange column was used for HPLC. This eliminates the protein displacement effect and the Gibbs-Donnan effect, thus permitting a rapid direct analysis. Three of the four ultrafiltration methods gave almost identical analytical results. Regression analyses of the results from direct serum injection versus ultrafiltration showed a bias of $5 \%$ on the slope $y=1.050 \cdot x_{\text {pure serum }}+1.856$, which was in our view solely due to the volume displacement effect of the proteins; correction of each data point by a protein-dependent correction factor resulted in an almost perfect regression line.
\end{abstract}

\section{Introduction}

The value of high-performance chromatography (HPLC) as an analytical method for the determination of creatinine in serum, depends on its design and application. Several publications report the use of this technique as a (candidate) reference method, or a selected method $(1-5)$.

In others, HPLC is simply used to measure creatinine concentrations in serum or urine $(6-10)$.

In the latter case, a rapid throughput and thus a minimal number of experimental steps is desired. In a reference technique, however, time is not as important as precision and accuracy. In both applications, it is necessary to remove proteins, either by acid precipitation or by ultrafiltration $(12,13)$ and irrespective of the chosen technique, the volume displacement effect of the removed proteins must be taken into account in the interpretation of the results.

The technique as described by us (5) is an easy-to-use and accurate back-up system for the comparison of large sets of creatinine samples. Because of the workload we felt the need to improve the absolute speed of our HPLC system (6 samples/hour).
We therefore considered two options for decreasing the operation time by a factor 2 or 3 :

a. use of a shorter column

b. increased flow.

In addition, we wished to investigate the problem of accucary by studying the ultrafiltration step in more detail. We therefore compared the ultrafiltration technique with a HPLC method developed by us, which does not involve deproteinization, and we also compared different ultrafiltration units.

\section{Materials and Methods}

Materials

Reagents

All chemicals were essentially the same as in our previous study (5).

The serum samples were stored for up to one month at $-80^{\circ} \mathrm{C}$ until further use.

Kontrollogen L and Kontrollogen LP control sera from Behringwerke A. G., Marburg, Germany, together with three reference sera (A, B, C) from the Deutsche Gesellschaft für Klinische Chemie (Zentrale Referenzinstitution) were used as con- 
trol material. In all sera, the creatinine was determined by isotope dilution-mass spectrometry and by a validated reference method.

The tested ultrafiltration units were:

a) Centrifree Micropartition System, Amicon Division, W. R. Grace \& Co., Beverly (U.S. A.).

b) Centrisart-I, Sartorius, Göttingen (Germany).

c) Ultracent, Bio-Rad Laboratories, Richmond (U.S. A.).

d) Ultrafree-MC, Millipore Product Division, Bedford (U.S. A.).

\section{Methods}

\section{Ultrafiltration}

The Centrifree Micropartition System needs a fixed-angle rotor (JA-21 Beckman, 20 min at $1000 \mathrm{~g}$ ) to provide an ultrafiltrate. The Ultrafree system was used in an Eppendorf (5414) centrifuge $(60 \mathrm{~min}$ at $10000 \mathrm{~g})$ with a fixed-angle rotor.

The other two systems, Ultracent and Centrisart-I can produce an ultrafiltrate in a centrifuge with a swing-head rotor (40 $\mathrm{min}$ at $2900 \mathrm{~g}$ ).

All four units carried a semipermeable membrane (cut-off $M_{\mathrm{r}} \approx 10000$ ).

Because of the volume displacement effect of the proteins, we used a protein-dependent factor to adjust for this change in volume according to Weast (14).

\section{Sample preparation}

A serum sample $(100-300 \mu$ l) was centrifuged for $20-40$ minutes and $10 \mu \mathrm{l}$ ultrafiltrate was directly injected into the HPLC system.

Direct injection of $5 \mu \mathrm{l}$ of a serum sample onto the same system needs no preparation, except for turbid samples, which can be clarified with a Seraclear ${ }^{\circledR}$ filter (Bayer-Technicon, Tarrytown, U.S. A.). Sera were diluted with a Microlab M dilutor (Hamilton, Switzerland); $1000 \mu$ l serum were diluted with 1000,2000 , 3000 or $4000 \mu \mathrm{l} \mathrm{NaCl}, 154 \mathrm{mmol} / \mathrm{l}$.

\section{Total protein determination}

We used the Technicon Chem-1 system for the total protein estimations (Biuret procedure).

\section{High performance liquid chromatography (HPLC)}

The HPLC system described in 1.c. (5) was used. We used the same weak cation-exchange column, with two appropriate modifications: the pore size was changed from 7 to $11 \mathrm{~nm}$, and the column dimensions were $100 \times 4.6 \mathrm{~mm} \mathrm{I}$. D. and $50 \times 4.6 \mathrm{~mm}$ I. D.

Flow rates were $1.0 \mathrm{ml} / \mathrm{min}$ for the $150 \mathrm{~mm}$ column, and 1.5 $\mathrm{ml} / \mathrm{min}$ for the $100 \mathrm{~mm}$ and the $50 \mathrm{~mm}$ columns.

\section{Statistical analysis}

Results were compared by regression analyses according to Passing \& Bablok (15). Significance of differences between medians of series of assay determinations was calculated with the Wilcoxon test for paired results; $\mathrm{p}<0.01$ was taken as significant.

\section{Results}

To evaluate the shorter columns we used a serum bank of 36 non-haemolytic, non-icteric and non-lipaemic sera with creatinine concentrations ranging from 40 to $1250 \mu \mathrm{mol} / \mathrm{l}$; these samples were also analysed with our original method.

The use of a slightly larger pore size for the stationary phase improved the peak shape considerably. Tailing peaks (fig. 1) were abolished, thereby improving the resolution of the creatinine peak. In combination with the increased flow-rate of $1.5 \mathrm{ml} / \mathrm{min}$, the retentiontime of creatinine decreased from $5.6 \mathrm{~min}$ to $4.2 \mathrm{~min}$ on the $100 \mathrm{~mm}$ and to $2.8 \mathrm{~min}$ on the $50 \mathrm{~mm}$ column. The $50 \mathrm{~mm}$ column was therefore chosen, because only with this column were we able to increase the total number of analyses from 6 to 12 per hour.
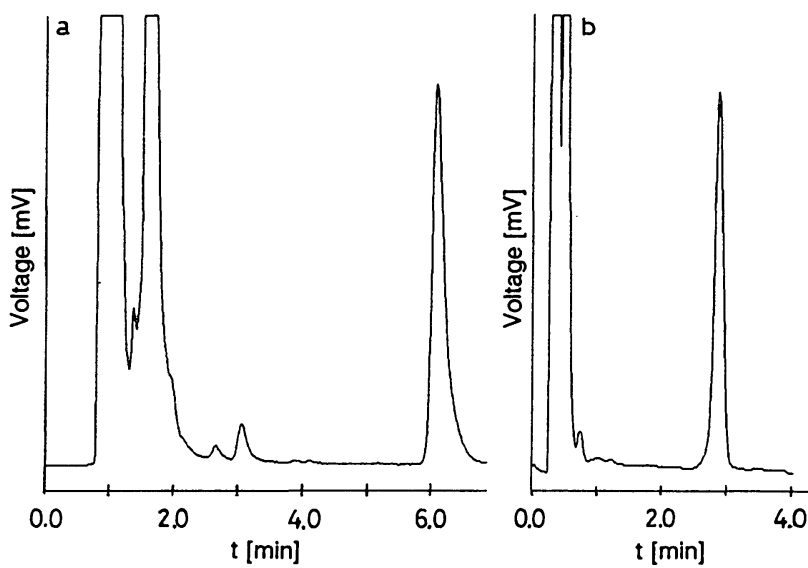

Fig. 1. The same ultrafiltrate analysed on the $150 \mathrm{~mm}$ colum (a), and on the $50 \mathrm{~mm}$ column (b), attenuation is 32 $\left(2^{5}\right)$.

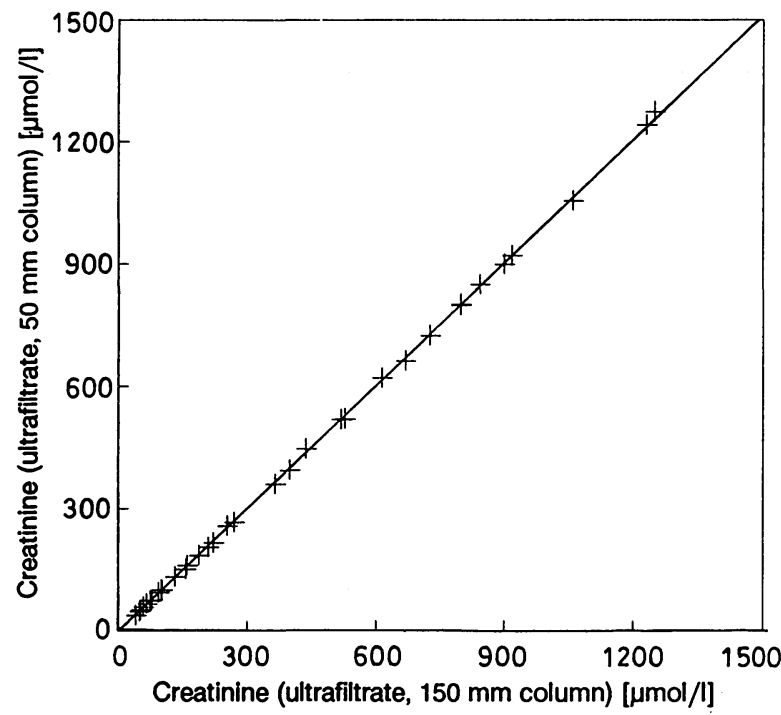

Fig. 2. The creatinine concentrations of 36 ultrafiltrates analysed on the $150 \mathrm{~mm}$ column (x-axis) and on the $50 \mathrm{~mm}$ column (y-axis), showing a perfect correlation. $\mathrm{Y}=1.006 \mathrm{x}-3.648 ; \mathrm{r}=0.99992$ 
Tab. 1. Method comparison $(y=a x+b)$ between the Centrifree MPS unit $(x)$ and three other ultrafiltration units (y).

\begin{tabular}{llllllrr}
\hline $\begin{array}{l}\text { Filtration } \\
\text { Unit }\end{array}$ & $\mathrm{a}$ & $\mathrm{b}$ & $\mathrm{n}$ & $\mathrm{r}$ & $\begin{array}{l}\text { Median } \mathrm{x} \\
(\mu \mathrm{mol} / \mathrm{l})\end{array}$ & $\begin{array}{l}\text { Median y } \\
(\mu \mathrm{mol} / \mathrm{l})\end{array}$ \\
\hline Ultracent $^{\mathrm{a}}$ & $0.991(0.987-0.994)$ & $-0.017(-0.486-0.941)$ & 36 & 0.99996 & 237.4 & 235.0 \\
Centrisart $^{\mathrm{b}}$ & $0.994(0.988-0.998)$ & $+0.171(-0.762-1.103)$ & 36 & 0.99987 & 237.4 & 237.4 \\
Ultrafree $^{\mathrm{c}}$ & $1.177(1.150-1.210)$ & $-1.075(-5.178-3.751)$ & 36 & 0.99631 & 237.4 & 270.1 \\
Ultrafree $^{\mathrm{d}}$ & $1.002(0.953-1.024)$ & $-0.956(-3.154-5.326)$ & 10 & 0.99967 & 90.8 & 87.3 \\
\hline
\end{tabular}

a Ultracent significantly different from Centrifree $(p<0.01)$.

${ }^{b}$ Centrisart not significantly different from Centrifree.

${ }^{d}$ Ultrafree used in a cold room $\left(4^{\circ} \mathrm{C}\right)$, not significantly different from Centrifree.

a-d Wilcoxon signed ranks test.

Note: data between brackets are the $95 \%$ confidence limits.

The results of the ultrafiltrates analysed on the 150 $\mathrm{mm}$ and the $50 \mathrm{~mm}$ column are plotted in figure 2 .

The correlation study showed an excellent regression line $\left(\mathrm{y}_{50 \mathrm{~mm}}=1.006 \mathrm{x}_{150 \mathrm{~mm}}-3.648\right)$, and $95 \%$ confidence interval $(\mathrm{r}=0.99992)$, with $1.001-1.010$ for the slope and $-4.855--2.013$ for the intercept. Median $\mathrm{x}=237.4 \mu \mathrm{mol} / \mathrm{l}$, median $\mathrm{y}=236.2 \mu \mathrm{mol} / \mathrm{l}$.

In a preliminary study we applied the Centrifree system, which suffers from the one drawback that it requires a fixed angle rotor centrifuge. We were therefore also interested in equivalent systems which only need a laboratory centrifuge with a swing rotor.

We used the $50 \mathrm{~mm}$ column to analyse the ultrafiltrates of the same 36 sera, and compared the results with those from the three other systems.

The Ultracent- and the Centrisart units gave nearly identical creatinine results, whereas the slope of the results from the Ultrafree unit showed a positive bias; we believe that this difference was due to the extremely long centrifugation time $(60-80 \mathrm{~min})$ at room temperature. When we repeated the experiment, with a subset of 10 serum samples in a cold room $\left(4^{\circ} \mathrm{C}, 60\right.$ $\mathrm{min}$ ), the results from the Ultrafree unit were identical to those from the Centrifree unit.

Statistics are summarized in table 1.

The differences between the tested ultrafiltration units, when properly used, are negligibly small, but on basis of the Wilcoxon signed ranks test only the Centrisart unit was not significantly different from the Centrifree filter.

The remaining question was how to study the validation of the ultrafiltration step irrespective of the column used. Ultrafiltration of serum is used to protect the analytical column, and it results in a slight rise of the creatinine concentration, due to the protein displacement effect. To compensate for this effect we used a protein (dependent) factor. However, to meas- ure the true creatinine concentration in serum, one has to inject the pure serum and consider this to be the golden standard. The correlation study of the 100 $\mathrm{mm}$ and the $150 \mathrm{~mm}$ column showed again an excellent regression line: $\mathrm{y}_{100 \mathrm{~mm}}=1.005 \mathrm{x}_{150 \mathrm{~mm}}-3.558$, $\mathrm{r}=0.99944(95 \%$ confidence interval), with 0.996 -1.016 for the slope and $-4.397--0.742$ for the intercept. Median $\mathrm{x}=237.4 \mu \mathrm{mol} / \mathrm{l}, \quad$ median $\mathrm{y}=238.7 \mu \mathrm{mol} / \mathrm{l}$

Therefore we used our experimental $100 \mathrm{~mm}$ column to compare a series of ultrafiltrates and pure sera, and we investigated whether the application of pure serum could be used to validate the protein correction factor.

The same 36 sera, together with 3 control sera, were analysed before and after ultrafiltration.

The Centrifree units were used to produce the ultrafiltrates.

The only drawback was the rapid deterioration of the column, which became very noticeable after about 70 injections. Two typical chromatograms are shown in figure 3. Nevertheless, we were able to use the column again after a rigorous clean-up ( 24 hours of dilute phosphoric acid pH 3 and 8 hours 100\% methanol).

The creatinine results correlate almost perfectly between pure serum and the ultrafiltrates, with a bias on the slope of only 1.050 .

Correction with a protein-dependent factor (tab. 2), or even with a fixed protein factor $(0.9465)$ removed all significant differences between the pure sera and the ultrafiltrates, confirming that the difference between ultrafiltrates and the native sera is mainly due to the protein displacement effect.

Because of the minor difference between the two calculation techniques we think that for routine analyses the use of a fixed protein factor is a valid option. The regression results are shown in table 3 . 

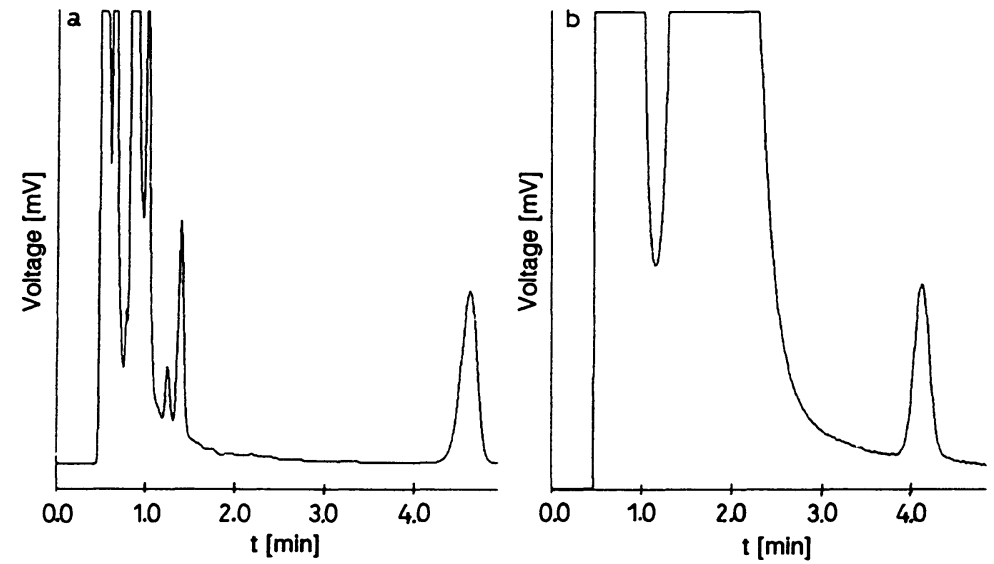

Fig. 3. A chromatogram of pure serum on a new column (a), and a chromatogram of pure serum after \pm 70 injections (b), analysed on the $100 \mathrm{~mm}$ column; attenuation is $8\left(2^{3}\right)$, injection volume $5 \mu$. The deterioration of the column can be seen in the void peak, and in a slight decrease in retention time.

Tab. 2. The correction of the creatinine concentration, on the basis of the total protein content of 36 sera, as described by Weast (14).

\begin{tabular}{|c|c|c|c|c|c|}
\hline Sample & $\begin{array}{l}\text { Protein } \\
(\mathrm{g} / \mathrm{l})\end{array}$ & Factor $^{1}$ & $\begin{array}{l}\text { Filtrate } \\
(\mu \mathrm{mol} / \mathrm{l})\end{array}$ & $\begin{array}{l}\text { Filtrate }^{2} \\
(\mu \mathrm{mol} / \mathrm{l})\end{array}$ & $\begin{array}{l}\text { Direct }^{3} \\
(\mu \mathrm{mol} / \mathrm{l})\end{array}$ \\
\hline 1 & 58 & 0.9566 & 43.7 & 41.8 & 39.1 \\
\hline 2 & 52 & 0.9606 & 53.7 & 51.0 & 50.2 \\
\hline 3 & 74 & 0.9444 & 70.8 & 66.9 & 66.7 \\
\hline 4 & 69 & 0.9485 & 83.3 & 79.0 & 77.8 \\
\hline 5 & 68 & 0.9485 & 99.6 & 94.4 & 95.8 \\
\hline 6 & 67 & 0.9495 & 139.6 & 132.5 & 130.1 \\
\hline 7 & 80 & 0.9404 & 171.0 & 160.8 & 162.0 \\
\hline 8 & 46 & 0.9657 & 194.6 & 188.0 & 185.4 \\
\hline 9 & 63 & 0.9525 & 231.8 & 220.8 & 222.1 \\
\hline 10 & 68 & 0.9485 & 284.9 & 270.2 & 270.3 \\
\hline 11 & 53 & 0.9606 & 380.0 & 365.0 & 359.7 \\
\hline 12 & 63 & 0.9525 & 418.3 & 398.5 & 400.2 \\
\hline 13 & 55 & 0.9586 & 541.2 & 518.8 & 520.5 \\
\hline 14 & 72 & 0.9465 & 647.7 & 613.0 & 615.1 \\
\hline 15 & 71 & 0.9465 & 766.5 & 725.4 & 729.4 \\
\hline 16 & 71 & 0.9465 & 842.5 & 797.4 & 804.6 \\
\hline 17 & 65 & 0.9505 & 946.9 & 900.0 & 892.1 \\
\hline 18 & 70 & 0.9465 & 1119.4 & 1059.4 & 1054.8 \\
\hline 19 & 55 & 0.9586 & 1303.1 & 1249.1 & 1223.3 \\
\hline 20 & 66 & 0.9505 & 79.2 & 75.3 & 73.5 \\
\hline 21 & 63 & 0.9525 & 63.0 & 60.0 & 57.4 \\
\hline 22 & 43 & 0.9677 & 53.0 & 51.3 & 50.4 \\
\hline 23 & 71 & 0.9465 & 55.7 & 52.7 & 49.2 \\
\hline 24 & 73 & 0.9444 & 108.6 & 102.6 & 98.2 \\
\hline 25 & 81 & 0.9394 & 166.8 & 156.7 & 154.5 \\
\hline 26 & 68 & 0.9485 & 105.6 & 100.1 & 98.9 \\
\hline 27 & 73 & 0.9444 & 81.2 & 76.7 & 73.4 \\
\hline 28 & 59 & 0.9545 & 220.1 & 210.1 & 206.8 \\
\hline 29 & 70 & 0.9470 & 268.4 & 254.2 & 251.6 \\
\hline 30 & 66 & 0.9505 & 459.7 & 436.9 & 432.7 \\
\hline 31 & 70 & 0.9470 & 842.0 & 796.9 & 772.2 \\
\hline 32 & 60 & 0.9545 & 882.7 & 842.6 & 856.9 \\
\hline 33 & 55 & 0.9586 & 1283.6 & 1230.4 & 1219.4 \\
\hline 34 & 47 & 0.9646 & 693.3 & 668.8 & 671.6 \\
\hline 35 & 63 & 0.9525 & 964.0 & 918.2 & 929.6 \\
\hline 36 & 67 & 0.9495 & 555.4 & 527.3 & 525.2 \\
\hline
\end{tabular}

${ }^{1}$ Factor as determined on basis of the protein content.

${ }^{2}$ Filtrate after correction with a protein-dependent factor.

${ }^{3}$ Injection of $5 \mu \mathrm{l}$ serum direct onto the HPLC column. 
Tab. 3. Method comparison $(y=a x+b)$ of 36 sera analysed as pure serum ( $x)$ and as ultrafiltrate (y).

\begin{tabular}{lllllll}
\hline & $\mathrm{a}$ & $\mathrm{b}$ & $\mathrm{n}$ & $\mathrm{r}$ & $\begin{array}{l}\text { Median } \mathrm{x} \\
(\mu \mathrm{mol} / \mathrm{l})\end{array}$ & $\begin{array}{l}\text { Median } \mathrm{y} \\
(\mu \mathrm{mol} / \mathrm{l})\end{array}$ \\
\hline Ultrafiltrate $^{\mathrm{a}}$ & $1.050(0.178-3.119)$ & $1.856(1.043-1.057)$ & 36 & 0.99979 & 236.9 & 250.1 \\
Ultrafiltrate $^{\mathrm{b}}$ & $0.993(0.986-1.000)$ & $1.755(0.168-2.949)$ & 36 & 0.99979 & 236.9 & 236.5 \\
Ultrafiltrate $^{\mathrm{c}}$ & $0.998(0.991-1.006)$ & $2.201(0.643-3.315)$ & 36 & 0.99988 & 236.9 & 237.4 \\
\hline
\end{tabular}

${ }^{a}$ Ultrafiltrate not corrected, y significantly different from $\mathrm{x}(\mathrm{p}<0.01)$.

b Ultrafiltrates corrected with a fixed factor of 0.9456 , y not significantly different from $x$.

c Ultrafiltrates corrected with a protein-dependent factor, y not significantly different from $x$.

a-c Wilcoxon signed ranks test.

Note: data between brackets are the $95 \%$ confidence limits.

Tab. 4. Accuracy of direct injection compared with that of the reference method and injection after ultrafiltration.

\begin{tabular}{lllll}
\hline Pool & $\begin{array}{l}\text { Reference } \\
\text { value }^{\mathrm{a}} \\
(\mu \mathrm{mol} / \mathrm{l})\end{array}$ & $\begin{array}{l}\mathrm{Mean}^{\mathrm{b}} \\
(\mu \mathrm{mol} / \mathrm{l})\end{array}$ & $\begin{array}{l}\text { SD } \\
(\mu \mathrm{mol} / \mathrm{l})\end{array}$ & $\begin{array}{l}\mathrm{CV} \\
(\%)\end{array}$ \\
\hline
\end{tabular}

\begin{tabular}{lllll}
\hline Pure sera & & & & \\
A & 155 & 152.9 & 2.4 & 1.5 \\
B & 221 & 214.5 & 1.7 & 0.8 \\
C & 593 & 585.9 & 7.9 & 1.4 \\
Ultrafiltrate & & & & \\
A & 155 & 152.5 & 1.3 & 0.9 \\
B & 221 & 213.5 & 2.2 & 1.0 \\
C & 593 & 588.4 & 3.9 & 0.7 \\
\hline
\end{tabular}

a Values determined by the reference method used by the 'Deutsche Gesellschaft für Klinische Chemie'.

${ }^{h}$ Mean values are calculated from $n=5$.

The accuracy of the modified procedure was investigated with 3 reference sera, and the results are summarized in table 4.

As the $100 \mathrm{~mm}$ column performed so well, we wondered if the costs of an analytical column could counterbalance the costs of the ultrafiltration units, if we used diluted sera to delay column deterioration.

Five dilutions $(1 \mathrm{ml}+0 \mathrm{ml}, 1 \mathrm{ml}+\ldots, 1 \mathrm{ml}+4 \mathrm{ml})$ were made of 5 normal serum pools. The resulting creatinine concentrations ranged from 79 to 456 $\mu \mathrm{mol} / \mathrm{l}$.

We checked the precision of the dilutor by diluting a serum sample $(1 \mathrm{ml}+2 \mathrm{ml}) 9$ times and found a mean of $127.5 \mu \mathrm{mol} / 1$, a SD of $0.54 \mu \mathrm{mol} / 1$ and a CV of $0.4 \%$.

These results are within the normal within-run precision of this method (Kontrollogen $\mathrm{L}$ mean $=121$ $\mu \mathrm{mol} / \mathrm{l}, \mathrm{SD}=1.7 \mu \mathrm{mol} / \mathrm{l}, \mathrm{CV} 1.4 \%)$.

Although the column performed for slightly longer with a reasonable selectivity (99 samples instead of 72), the experiments were not convincing. After 309 injections the column was unfortunately destroyed.

\section{Discussion}

The use of a $50 \mathrm{~mm}$ column in combination with the increased flow of $1.5 \mathrm{ml} / \mathrm{min}$ made it possible to cut down the overall run time for one creatinine determination from approximately $9 \mathrm{~min}$ to $4.5 \mathrm{~min}$. This means that in an "emergency", the method is now more suited for problematic routine samples.

Using the short column, the time for incubation, calibration with 3 standards and the measurement of the sample and a control sample is now less than 1 hour.

The choice of the ultrafiltration unit is arbitrary. On basis of the Wilcoxon test, we found no difference between the Centrifree and the Centrisart filter. We therefore prefer the Centrisart unit because it produces an ultrafiltrate in a simple laboratory centrifuge.

The price of an ultrafiltration unit is high ( \pm Dfl 5.00 per unit). An HPLC column is also expensive. The break-even point of the HPLC column is about 400 injections, but we did not reach that point. After approximately 300 injections and 3 clean-ups, the peak shape was such that we decided to replace the column.

Nevertheless the use of direct serum injection is possible, and it is a very simple and reliable way to evaluate reference and control sera.

In conclusion, for the determination of creatinine, HPLC with a modified weak cation exchanger and a column length of $50 \mathrm{~mm}$ or even less, is faster than the modification we described earlier, and peak-shape is improved considerably. Application of a fixed protein factor means that it is also a simple and sufficiently accurate back-up system for patient sera. Ultrafiltration is necessary to obtain a clean HPLC sample. When ultrafiltered samples are used, the column has an almost infinite lifetime (our first $150 \mathrm{~mm}$ column is still in use after \pm 4000 injections. 
Direct serum injection circumvents the use of a protein correction factor and is in our view an elegant way to upgrade our method to a reference method for the evaluation of reference material.

\section{References}

1. Weatherburn, M. W., Trotman, R. B. B. \& Jackson, S. H. (1978) Specific method for serum creatinine determination based on ion exchange chromatography and an automated alkaline picrate reaction. A proposed reference method. Clin. Biochem. 4, 159-166.

2. Schumann, G. \& Büttner, J. (1986) A candidate reference method for creatinine with HPLC. Z. Anal. Chem. 324, $278-279$.

3. Rosano, G. T., Ambrose, R. T., Wu, A. H. B., Swift, T. W. \& Yadegarl, P. (1990) Candidate reference method for determining creatinine in serum: Method development and interlaboratory validation. Clin. Chem. 36, 1951-1955.

4. Linnet, K. \& Bruunshuus, I. (1991) HPLC with enzymatic detection as a candidate reference method for serum creatinine. Clin. Chem. 37, 1669-1675.

5. Zwang, L. \& Blijenberg, B. G. (1991) Assessment of a selected method for creatinine with a special emphasis on bilirubin interference. Eur. J. Clin. Chem. Clin. Biochem. $29,795-800$.

6. Okuda, T., Oie, T. \& Nishida, M. (1983) Liquid-chromatography measurement of creatinine in serum and urine. Clin. Chem. 29, 851-853.

7. Spierto, F. W., MacNeil, M. L., Culbreth, P., Duncan, I. \& Burtis, C. A. (1980) Development and validation of a liquid chromatographic procedure for serum creatinine. Clin. Chem. 26, 286-290.

8. Kågedal, B. \& Olssen, B. (1990) Determination of creatinine in serum by high performance liquid chromatography: a comparison of three ion-exchange methods. J. Chrom. $527,21-30$

\section{Acknowledgement}

We would like to thank Prof. Dr. G. Röhle (Deutsche Gesellschaft für Klinische Chemie, Zentrale Referenzinstitution, Bonn) for kindly providing the reference sera, Bio-Rad (The Netherlands) for donating the experimental columns and $R$. W. Wulkan for his invaluable statistical support.

9. Guy, J. M. \& Legg, E. F. (1990) An improved cation exchange HPLC method for the measurement of serum creatinine. Ann. Clin. Biochem. 27, 223-226.

10. Harmoinen, A., Sillanaukee, P. \& Jokela, H. (1991) Determination of creatinine in serum and urine by cation-exchange high-pressure liquid chromatography. Clin. Chem. $37,563-565$.

11. Ekelund, S. \& Påby, P. (1991) High-performance liquid chromatography determination of creatinine. Scand. J. Lab. Invest. 51, 67-71.

12. da Fonseca-Wollheim, F., Heinze, K. G., Lomsky, K. \& Schreiner, H. (1988) Serum ultrafiltration for the elimination of endogenous interfering substances in creatinine determination. J. Clin. Chem. Clin. Biochem. 26, 523-525.

13. da Fonseca-Wollheim, F. (1989) Ultrafiltrate analysis for the detection of analytical error caused in routine methods by high molecular sample matrix. J. Clin. Chem. Clin. Biochem. 27, 735.

14. Weast, R. C. (ed.) Handbook of Chemistry and Physics, The Chemical Rubber Co., 18901 Crasewood Parkway, Cleveland, Ohio, 44128 55th edition (1974-1975) D-221.

15. Passing, H. \& Bablok, W. (1983) A new biomedical procedure for testing the equality of measurements from two different analytical methods. J. Clin. Chem. Clin. Biochem. $21,709-720$.

\section{Zwang}

Academic Hospital Rotterdam-Dijkzigt

Department of Clinical Chemistry

Dr. Molewaterplein 40

NL-3015 GD Rotterdam

The Netherlands 